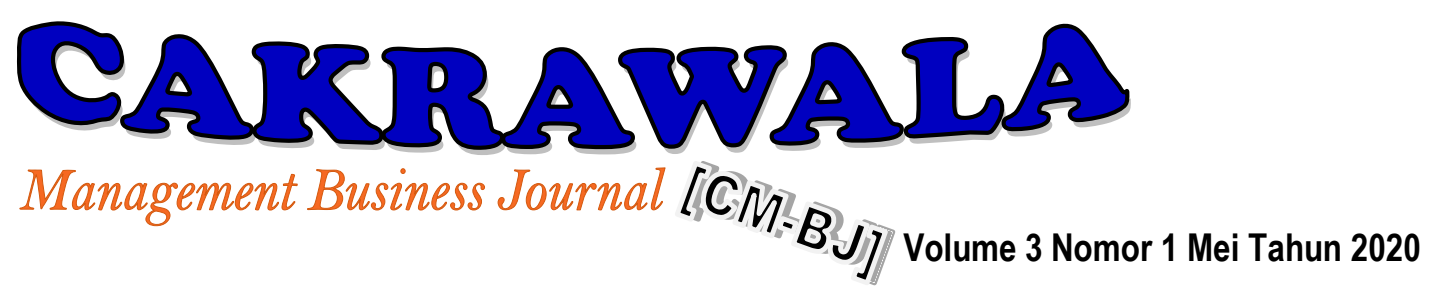

\title{
DEMOGRAFI PENGGUNA PRODUK DIGITAL ASLI KOTA PONTIANAK METODE CROSSTABS
}

\author{
Wenny Pebrianti ${ }^{1}$, Ahmadi $^{2}$ \\ Universitas Tanjungpura ${ }^{1,2}$
}

Page | - $571-$

Correspondence Email : wennypebrianti85@gmail.com

\begin{abstract}
ABSTRAK
Penelitian ini bertujuan untuk mengetahui tanggapan masyarakat Kota Pontianak terhadap produk digital asli Pontianak dengan memeriksa asosiasi berdasarkan kategori jenis kelamin, usia, pendidikan, pekerjaan, pendapatan, dan frekuensi penggunaan dengan metode tabulasi silang.

Penelitian adalah penelitian deskriptif. Populasi dalam penelitian ini adalah masyarakat Kota Pontianak yang telah menggunakan layanan produk digital Pontianak, yaitu Angkuts, Tripy dan Gurukite.com. Ukuran sampel 100 responden dipilih dengan purposive sampling, sedangkan kriteria sampel adalah responden dengan usia di atas atau sama dengan 17 tahun, tahu dan telah menggunakan layanan Angkuts, Tripy atau Gurukite.com. Teknik pengolahan data menggunakan analisis tabulasi silang dan pengujian asosiasi dengan chi square.

Hasil tabulasi silang dan chi square antara kategori jenis kelamin, usia, pendidikan, pekerjaan, pendapatan dan frekuensi penggunaan menunjukkan hasil yang signifikan. Ada hubungan strategis antara variabel kategori untuk ditindaklanjuti oleh pengusaha digital pontianak.
\end{abstract}

\section{ABSTRACT}

This study aims to determine the response of Pontianak City people to the original digital products of Pontianak by examining the association based on the category of gender, age, education, occupation, income and frequency of use with cross tabulation method.

Research is descriptive research. The population in this study is the people of Pontianak City who have used digital product services from Pontianak, namely Angkuts, Tripy and Gurukite.com. The sample size of 100 respondents was selected by purposive sampling, while the sample criteria were respondents with ages above or equal to 17 years, knew and had used Angkuts, Tripy or Gurukite.com services. Data processing techniques use cross tabulation analysis and association testing with chi square.

The results of cross tabulation and chi square between categories of gender, age, education, occupation, income and frequency of use showed significant results. There is a strategic relationship between categorical variables to be followed up by pontianak digital businessmen.

Keywords: smart city, crosstabulation, chi square, digital, demografi 


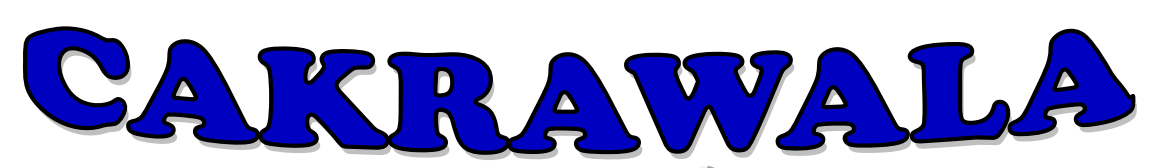

\section{Management Business Journal [CM:-B]] Volume 3 Nomor 1 Mei Tahun 2020}

\section{PENDAHULUAN}

Pesatnya tingkat urbanisasi menimbulkan berbagai masalah di kota sehingga mendesak pemerintah untuk menyelesaikan masalah yang disebabkan oleh populasi yang tinggi. Dalam menghadapi masalah perkotaan sambil mempertahankan kinerjanya, beberapa konsep konstruksi dan pengelolaan kota sedang dikembangkan, salah satunya adalah melalui konsep kota pintar (smart city) yakni manajemen dan pengembangan kota berdasarkan teknologi informasi dan komunikasi (Dameri, 2013). Perusahaan besar IBM, salah satu pelopor konsep ini, menggunakan konsep ini untuk mempromosikan produk inovasinya yang dikenal dengan Big Data dalam konsep Smart Planet pada 2008 (Cocchia, 2014).

Lebih dari 50\% populasi global di perkotaan (United Nations Report, 2012). Kompleksitas ekosistem sosial di kota dan daerah perkotaan telah meningkat menjadikan keberlanjutan sebagai faktor penting. Masalah yang berkaitan dengan kesehatan, lalu lintas, polusi, kelangkaan sumber daya, pengelolaan limbah dan infrastruktur yang buruk muncul dan karenanya pembangunan kota berantakan. Masalah-masalah ini melemahkan pertumbuhan kota (Dawes, Cresswell \& Pardo 2009). Ini memicu penggunaan teknologi sebagai solusi dari semua masalah ini dan untuk mengatasinya dengan cara yang lebih cerdas. Karenanya konsep Kota Pintar diperkenalkan. Smart Cities memastikan lingkungan yang berkelanjutan dengan bantuan Big Data dan Internet of Things. Dengan "kota pintar", kami maksudkan bahwa kota ini lebih berkelanjutan, layak huni dan efisien. Pengguna konsep kota pintar diperkirakan mencapai pengeluaran tahunan sekitar \$16 miliar pada tahun 2020 (Pike Research, 2011).

Konsep Smart City atau Kota Pintar pada dasarnya telah digagas dan mulai diterapkan di kotakota pada negara maju sejak awal milenium baru yang lalu. Fenomena ini tidak lepas dari kemajuan teknologi internet yang mulai digunakan dalam banyak aspek kehidupan pada saat itu. Internet dengan fitur World Wide Web-nya yang pada awalnya hanya digunakan oleh kalangan pemerintah dan akademisi, kemudian berkembang dengan sangat pesat hingga saat ini menjadi media komunikasi dan transaksi massal yang mempengaruhi seluruh aspek kehidupan (Coe et al., 2001). Adapun data Produk Digital Asli Kota Pontianak tahun 2015-2016 terlihat pada tabel 1 dibawah ini :

Tabel 1.

Data Produk Digital Asli Kota Pontianak tahun 2015-2016

\begin{tabular}{ccc}
\hline Berdiri Tahun & Produk Digital & Jasa yang Ditawarkan \\
\hline 2015 & Bujang Kurir & Penyedia antar atau kurir apa saja \\
2015 & Angkuts & Angkut sampah \\
2016 & Travella & Layanan pesan taksi dan transportasi online \\
2016 & Tripy & Layanan penumpang orang dan lainnya \\
2016 & Gurukite.com & Penyedia guru privat online \\
\hline
\end{tabular}

Sumber : www.pontianakdigitalstream.id, 2016

Sehubungan dengan sedang berkembangnya konsep Smart City, memicu pemuda-pemuda di Kota Pontianak untuk turut berinovasi menciptakan produk digital yang bermanfaat bagi warga Pontianak. Kebanyakan setiap produk digital memiliki keragaman jenisnya masing-masing dalam 


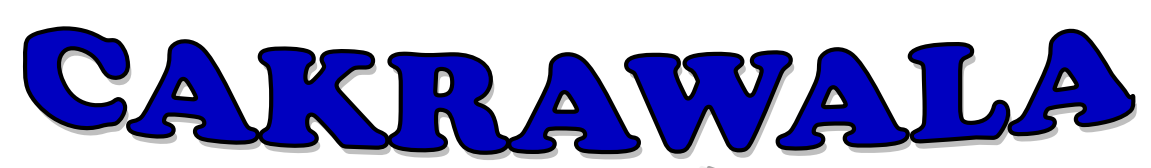

\section{Management Business Journal [CM:-BJ]] Volume 3 Nomor 1 Mei Tahun 2020}

produk yang ditawarkan, sehingga para pengusaha harus mempunyai strategi yang ketat dan nilai jual yang lebih untuk menjadi yang terbaik.

Riset ini memetakan dan menguji asosiasi atau hubungan antar variabel demografi (usia, jenis kelamin, pendidikan, pendapatan, pekerjaan, frekuensi menggunakan) pengguna produk digital asli pontianak dengan memilih tiga produk digital sebagai objek penelitian berdasarakan keterwakilan dari beberapa bidang produk dan berdasarkan banyaknya unduhan di Google Play Store. Bersumber dari data yang penulis peroleh dari Google Play Store, Tripy yang mewakili bidang transportasi mengungguli banyaknya unduhan aplikasi dari semua produk digital asli Kota Pontianak dengan jumlah 5000 unduhan, diikuti Angkuts yang mewakili bidang lingkungan dan Gurukite.com yang masih berbasis website mewakili bidang pendidikan dengan jumlah 653 pengguna jasa. Sampel akan fokus pada pengguna jasa ketiga produk tersebut yakni pengguna Tripy, Gurukite.com dan Angkuts.

Analisis demografi dalam penelitian pemasaran lazim digunakan untuk merancang produk dan menetapkan segmen pasar yang sesuai. Segmentasi pasar adalah proses membagi- bagi pasar yang semula berperilaku heterogen menjadi beberapa kelompok pasar yang sekarang berperilaku yang lebih seragam atau dapat pula dikatakan suatu proses mengelompokkan bagian- bagian pasar yang berperilakunya sama dari keseluruhan perilaku pasar yang seragam (Kotler, Gary dan Amstrong, 2012). Secara umum tujuan dari segmentasi pasar adalah untuk memperoleh bagian pasar yang mempunyai karakter dan perilaku yang lebih seragam. Djaswadi, Wibowo dan Kunaifi (2017) melakukan metode crosstabs untuk memetakan karakteristik konsumen taxi ride sharing di Surabaya. Sejalan dengan Pradita (2015) juga menganalisis korelasi karakteristik responden dengan faktor keputusan konsumen menjadi member tupperware di Yogyakarta dengan menggunakan metode crosstabs dan chi square analysis.

\section{METODE PENELITIAN}

Penelitian ini merupakan penelitian deskriptif kuantitatif yang bertujuan untuk menjelaskan suatu fenomena empiris yang disertai data statistik, karakteristik, dan pola hubungan antar variabel. Sampel dalam penelitian ini adalah masyarakat pengguna jasa Angkuts, Tripy dan Gurukite.com sebanyak 100 orang responden.

Metode sampling yang digunakan adalah non probability sampling menggunakan purposive sampling, yang merupakan teknik pengambilan sampel dengan beberapa pertimbangan (Kuncoro, 2003). Kriteria responden dalam penelitian ini adalah pengguna jasa salah satu produk digital kota Pontianak (Trippy, Gurukite.com dan Angkuts) yang berusia minimal 17 tahun karena dianggap sudah mampu membuat keputusan sehingga dapat mengisi kuesioner dengan baik dan benar. Data akan dianalisis dengan Metode Analisis Tabulasi Silang (Crosstabs) dan Uji Chi-Square. Analisis tabulasi silang (Crosstabs) adalah metode analisis yang paling sederhana tetapi memiliki daya menerangkan cukup kuat untuk menjelaskan hubungan antar variabel (Sugiyono, 2011). Untuk itu ada beberapa prinsip sederhana yang perlu diperhatikan dalam menyusun tabel silang agar hubungan antara variabel tampak dengan jelas. Untuk itu maka dalam analisis crosstabs digunakan analisis statistik Chi Square (Ghozali, 2001). Analisis crosstabs dilakukan pada variabel usia, jenis 


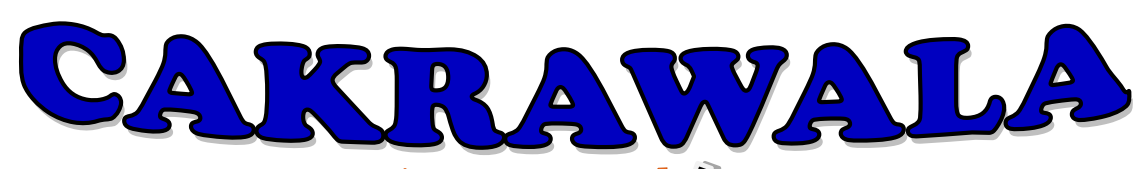

\section{Management Business Journal [CM:-BJ] Volume 3 Nomor 1 Mei Tahun 2020}

kelamin, pendidikan, pekerjaan dan pendapatan sesuai dengan coding/kategori dalam tabel operasional dibawah ini :

Tabel 2.

Operasionalisasi Variabel

\begin{tabular}{llr} 
& \multicolumn{1}{c}{ Kategori } & Kod \\
\cline { 2 - 4 } Page | - $574-$ & & 1 \\
& -17 tahun & 2 \\
& $-23-27$ & 3 \\
& $-28-32$ & 4 \\
& $-33-37$ & 5 \\
& $-38-42$ & 6 \\
& $->42$ &
\end{tabular}

Jenis Kelamin :

Pendidikan :

- Laki-laki 1

- Perempuan 2

- SMA 1

- Diploma 2

- Sarjana 3

Pekerjaan :

- Pasca sarjana 4

- PNS 1

- Wirausaha 2

- Pegawai swasta 3

- Pelajar / mahasiswa 4

- BUMN 5

- Lainnya 6

Pendapatan (rupiah) :

- 500-1 juta 1

- $1-1.5$ juta 2

- $1.5-2$ juta 3

- $2-2.5$ juta 4

- $2.5-3$ juta $\quad 5$

- $>3$ juta 6

\section{HASIL PENELITIAN}

\section{Karakteristik Responden}

Penelitian dilakukan dengan menyebar daftar pertanyaan isian demografi secara langsung kepada responden untuk di isi. Penyebaran data berlangsung sejak September sampai dengan November 2018. Diperolah 112 responden, setelah dilakukan pengecekan kelengkapan jawaban hanya 100 responden yang jawabannya di analisis untuk tahapan selanjutnya.

Tabel 3. 


\section{CAIrRaWALA}

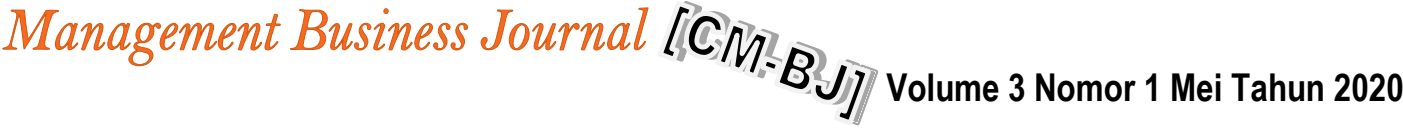

Komposisi Responden

\begin{tabular}{cc}
\hline Produk Digital & Jumlah Responden \\
\hline Angkuts & 32 \\
Tripy & 34 \\
Gurukite.com & 34 \\
Total & 100 \\
\hline
\end{tabular}

Page | - 575

\section{Hasil crosstab Usia dan Pendapatan}

Responden dalam penelitian ini dari kategori usia dan pendapatan seperti tabel dibawah ini. Ada 9 orang yang berusia 17 tahun pada tingkat pendapatan 500ribu sd 1 juta rupiah, 8 orang berusia 18 - 22 tahun pada tingkat pendapatan 500ribu sd 1 juta rupiah. Responden usia $23-27$ orang sebanyak 26 orang dan mayoritas pada tingkat pendapatan $2-2,5$ juta. Usia $28-32$ tahun sebanyak 21 orang yang di dominasi oleh mereka pada tingkat pendapatan $2.5-3$ juta. Selanjutnya usia 33 - 37 tahun sebanyak 5 orang didominasi oleh mereka pada tingkat pendapatan > 3 juta. Usia $38-42$ tahun sebanyak 21 orang didominasi oleh mereka pada tingkat pendapatan $>3$ juta. Kategori usia terakhir $>42$ tahun sebanyak 11 orang juga sebagian besar pada tingkat penghasilan > 3 juta.

Tabel 4.

Usia. penp Crosstabulation

\begin{tabular}{|c|c|c|c|c|c|c|c|c|c|}
\hline \multicolumn{10}{|c|}{ usia * penp Crosstabulation } \\
\hline & & & \multicolumn{6}{|c|}{ Penp } & \multirow[t]{2}{*}{ Total } \\
\hline & & & 1,00 & 2,00 & 3,00 & 4,00 & 5,00 & 6,00 & \\
\hline \multirow[t]{7}{*}{ Usia } & 1,00 & Count & 9 & 0 & 0 & 0 & 0 & 0 & 9 \\
\hline & 2,00 & Count & 8 & 0 & 0 & 0 & 0 & 0 & 8 \\
\hline & 3,00 & Count & 1 & 3 & 7 & 9 & 1 & 5 & 26 \\
\hline & 4,00 & Count & 0 & 0 & 0 & 0 & 19 & 1 & 20 \\
\hline & 5,00 & Count & 0 & 0 & 0 & 0 & 0 & 5 & 5 \\
\hline & 6,00 & Count & 0 & 0 & 0 & 0 & 0 & 21 & 21 \\
\hline & 7,00 & Count & 0 & 0 & 0 & 0 & 0 & 11 & 11 \\
\hline \multirow[t]{5}{*}{ Total } & & Count & 18 & 3 & 7 & 9 & 20 & 43 & 100 \\
\hline & & Expected Count & 18,0 & 3,0 & 7,0 & 9,0 & 20,0 & 43,0 & 100,0 \\
\hline & & $\%$ within usia & $18,0 \%$ & $3,0 \%$ & $7,0 \%$ & $9,0 \%$ & $20,0 \%$ & $43,0 \%$ & $100,0 \%$ \\
\hline & & $\%$ within penp & $100,0 \%$ & $100,0 \%$ & $100,0 \%$ & $100,0 \%$ & $100,0 \%$ & $100,0 \%$ & $100,0 \%$ \\
\hline & & $\%$ of Total & $18,0 \%$ & $3,0 \%$ & $7,0 \%$ & $9,0 \%$ & $20,0 \%$ & $43,0 \%$ & $100,0 \%$ \\
\hline
\end{tabular}

\section{Hasil Chi Square Test}

Chi square test digunakan untuk menguji apakah ada asosiasi atau hubungan antara usia dan pendapatan. Hasil chi square menunjukkan nilai sebesar 246,576 dengan probabilitas signifikan 0,000 . Oleh karena signifikansi $<0,05$ maka dapat disimpulkan terdapat hubungan antara usia dan pendapatan. 


\section{Management Business Journal [CM:-B]] Volume 3 Nomor 1 Mei Tahun 2020}

Tabel 5.

Chi-Square Tests

Page | - $576-$

\begin{tabular}{|c|c|c|c|}
\hline \multicolumn{4}{|c|}{ Chi-Square Tests } \\
\hline & Value & Df & $\begin{array}{c}\text { Asymptotic } \\
\text { Significance (2-sided) }\end{array}$ \\
\hline Pearson Chi-Square & $246,576^{a}$ & 30 & ,000 \\
\hline Likelihood Ratio & 212,421 & 30 & ,000 \\
\hline Linear-by-Linear Association & 71,285 & 1 & ,000 \\
\hline $\mathrm{N}$ of Valid Cases & 100 & & \\
\hline
\end{tabular}

a. 38 cells $(90,5 \%)$ have expected count less than 5 . The minimum expected count is, 15 .

Hasil ini menunjukkan bahwa pengguna produk digital pontianak dari segi usia mayoritas berasal dari usia 23 - 37 tahun dengan tingkat pendapatan lebih dari 3 juta perbulan. Ini menunjukkan pasar potensial dari Angkuts, Tripy dan Gurukite.com adalah mereka yang berasal dari kalangan muda dengan tingkat pendapatan menengah keatas.

\section{Hasil crosstab Usia dan Frekuensi}

Responden dalam penelitian ini dari kategori usia dan frekuensi menggunakan seperti tabel dibawah 4.3 Ada 9 orang yang berusia 17 tahun yang menggunakan produk digital sebanyak 1 kali, 8 orang berusia 18 - 22 tahun juga menggunakan produk digital 1 kali. pada tingkat pendapatan 500ribu sd 1 juta rupiah. Responden usia 23 - 27 orang sebanyak 26 orang dan mayoritas menggunakan produk digital sebanyak 2 kali. Usia 28 - 32 tahun sebanyak 20 orang yang di dominasi oleh mereka yang menggunakan produk digital sebanyak 2 kali. Selanjutnya usia 33 - 37 tahun sebanyak 5 orang didominasi oleh mereka dengan frekuensi menggunakan produk digital sebanyak 3 kali. Usia 38-42 tahun sebanyak 21 orang didominasi oleh mereka dengan frekuensi menggunakan sebanyak 3 kali. Kategori usia terakhir > 42 tahun sebanyak 11 orang yang menggunakan produk digital lebih dari 3 kali.

Tabel 6.

Hasil crosstab Pendidikan dan Jenis Kelamin

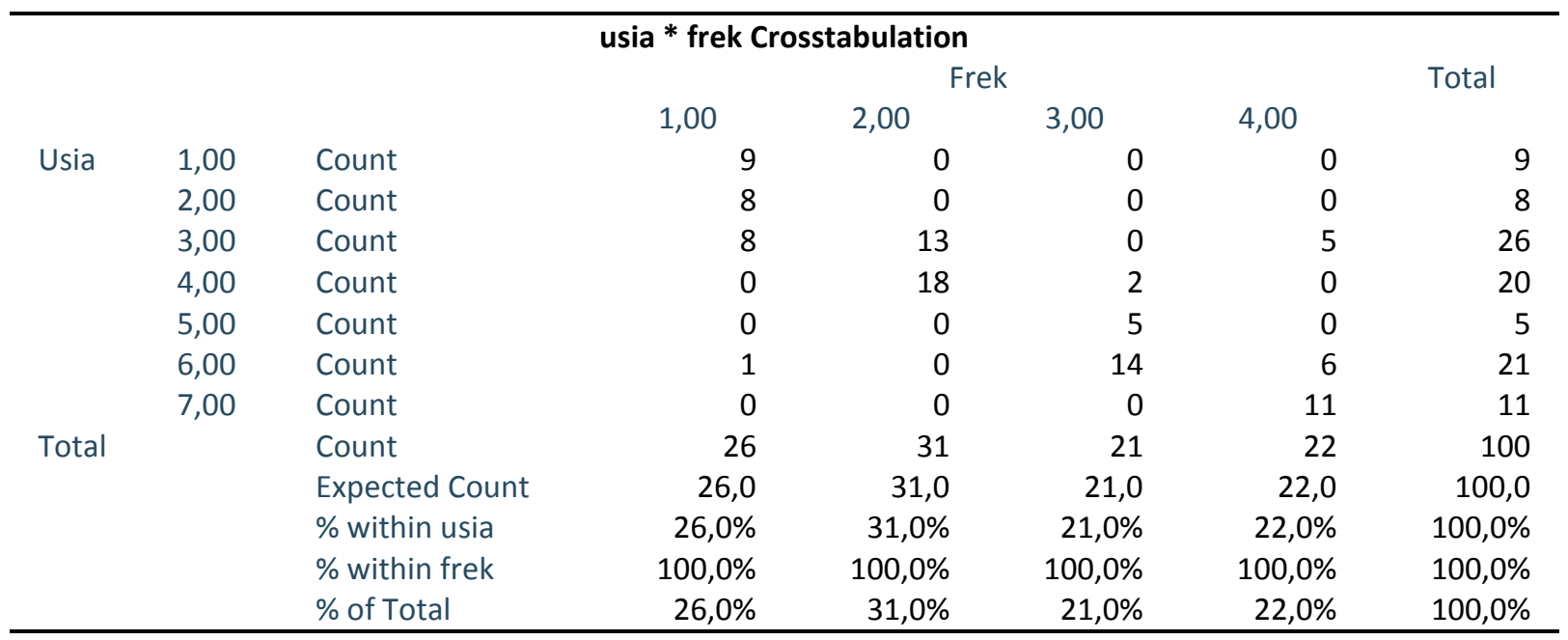

Hasil Chi Square Test 
Chi square test digunakan untuk menguji apakah ada asosiasi atau hubungan antara usia dan frekuensi menggunakan. Hasil chi square menunjukkan nilai sebesar 179,630 dengan probabilitas signifikan 0,000. Oleh karena signifikansi $<0,05$ maka dapat disimpulkan terdapat hubungan antara usia dan frekuensi menggunakan produk digital.

Tabel 7.

Chi - Squre Tests

\begin{tabular}{l|r|r|r} 
& \multicolumn{2}{c}{ Chi-Square Tests } & \multicolumn{2}{c}{$\begin{array}{c}\text { Asymptotic } \\
\text { Value }\end{array}$} & Df & Significance (2-sided) \\
\hline Pearson Chi-Square & $179,630^{\text {a }}$ & 18 &, 000 \\
\hline Likelihood Ratio & 175,985 & 18 &, 000 \\
\hline Linear-by-Linear Association & 63,095 & 1 &, 000 \\
\hline N of Valid Cases & 100 & & \\
\hline
\end{tabular}

a. 20 cells $(71,4 \%)$ have expected count less than 5 . The minimum expected count is 1,05 .

Hasil ini menunjukkan bahwa pengguna produk digital pontianak dari segi usia mayoritas berasal dari usia 23 - 37 tahun dengan frekuensi menggunakan 2 kali. Ini mengarahkan pasar potensial dari Angkuts, Tripy dan Gurukite.com adalah mereka yang berasal dari kalangan muda dengan aktivitas beragam. Akan tetapi yang paling sering menggunakan produk digital adalah responden usia $>42$ tahun, mereka sudah menggunakan jasa ini lebih dari 3 kali. Katagori segmen ini menarik untuk di ekplorasi dalam meningkatkan loyalitas penggunaan jasa produk digital pontianak.

\section{Hasil crosstab Pendidikan dan Jenis Kelamin}

Responden dalam penelitian ini dari kategori Pendidikan dan Jenis Kelamin menggunakan seperti tabel.7. Ada 31 orang laki-laki pengguna produk digital pontianak dari tingkat pendidikan SMA, 20 orang laki-laki dan 5 orang perempuan dari tingkat pendidikan diploma. Pada tingkat pendidikan sarjana terdapat 41 orang perempuan dan pasca sarjana juga 3 orang perempuan.

Tabel 8.

Hasil crosstab Pendidikan dan Jenis Kelamin

\begin{tabular}{|c|c|c|c|c|c|}
\hline \multicolumn{6}{|c|}{ pend * JK Crosstabulation } \\
\hline & & & \multicolumn{2}{|c|}{ JK } & Total \\
\hline & & & 1,00 & 2,00 & \\
\hline \multirow[t]{10}{*}{ Pend } & 1,00 & Count & 31 & 0 & 31 \\
\hline & & Expected Count & 15,8 & 15,2 & 31,0 \\
\hline & & $\%$ within pend & $100,0 \%$ & $0,0 \%$ & $100,0 \%$ \\
\hline & & \% within JK & $60,8 \%$ & $0,0 \%$ & $31,0 \%$ \\
\hline & & $\%$ of Total & $31,0 \%$ & $0,0 \%$ & $31,0 \%$ \\
\hline & 2,00 & Count & 20 & 5 & 25 \\
\hline & & Expected Count & 12,8 & 12,3 & 25,0 \\
\hline & & $\%$ within pend & $80,0 \%$ & $20,0 \%$ & $100,0 \%$ \\
\hline & & \% within JK & $39,2 \%$ & $10,2 \%$ & $25,0 \%$ \\
\hline & & $\%$ of Total & $20,0 \%$ & $5,0 \%$ & $25,0 \%$ \\
\hline
\end{tabular}




\section{cakrawala}

\section{Management Business Journal [CM:-B] J] Volume 3 Nomor 1 Mei Tahun 2020}

\begin{tabular}{|c|c|c|c|c|c|}
\hline \multicolumn{6}{|c|}{ pend * JK Crosstabulation } \\
\hline & & & \multicolumn{2}{|c|}{$\mathrm{JK}$} & Total \\
\hline \multirow{5}{*}{\multicolumn{2}{|c|}{3,00}} & Count & 0 & 41 & 41 \\
\hline & & Expected Count & 20,9 & 20,1 & 41,0 \\
\hline & & $\%$ within pend & $0,0 \%$ & $100,0 \%$ & $100,0 \%$ \\
\hline & & \% within JK & $0,0 \%$ & $83,7 \%$ & $41,0 \%$ \\
\hline & & $\%$ of Total & $0,0 \%$ & $41,0 \%$ & $41,0 \%$ \\
\hline \multirow{10}{*}{ Total } & 4,00 & Count & 0 & 3 & 3 \\
\hline & & Expected Count & 1,5 & 1,5 & 3,0 \\
\hline & & $\%$ within pend & $0,0 \%$ & $100,0 \%$ & $100,0 \%$ \\
\hline & & \% within JK & $0,0 \%$ & $6,1 \%$ & $3,0 \%$ \\
\hline & & $\%$ of Total & $0,0 \%$ & $3,0 \%$ & $3,0 \%$ \\
\hline & & Count & 51 & 49 & 100 \\
\hline & & Expected Count & 51,0 & 49,0 & 100,0 \\
\hline & & $\%$ within pend & $51,0 \%$ & $49,0 \%$ & $100,0 \%$ \\
\hline & & \% within JK & $100,0 \%$ & $100,0 \%$ & $100,0 \%$ \\
\hline & & $\%$ of Total & $51,0 \%$ & $49,0 \%$ & $100,0 \%$ \\
\hline
\end{tabular}

\section{Hasil Chi Square Test}

Chi square test digunakan untuk menguji apakah ada asosiasi atau hubungan antara pendidikan dan jenis kelamin. Hasil chi square menunjukkan nilai sebesar 83,994 dengan probabilitas signifikan 0,000. Oleh karena signifikansi $<0,05$ maka dapat disimpulkan terdapat hubungan antara pendidikan dan jenis kelamin pengguna produk digital asli Pontianak.

Tabel. 9.

\section{Chi -Square Tests}

\section{Chi-Square Tests}

\begin{tabular}{|c|c|c|c|}
\hline & Value & df & $\begin{array}{c}\text { Asymptotic } \\
\text { Significance (2-sided) }\end{array}$ \\
\hline Pearson Chi-Square & $83,994^{a}$ & 3 & ,000 \\
\hline Likelihood Ratio & 113,569 & 3 & 000 \\
\hline Linear-by-Linear Association & 74,596 & 1 & 000 \\
\hline $\mathrm{N}$ of Valid Cases & 100 & & \\
\hline
\end{tabular}

a. 2 cells $(25,0 \%)$ have expected count less than 5 . The minimum expected count is 1,47 .

Hasil ini menunjukkan bahwa pengguna produk digital pontianak dari segi pendidikan dan jenis kelamin adalah konsumen pasca sarjana dan perempuan. Perempuan dengan tingkat pendidikan tinggi akrab dengan teknologi informasi dan aktif menggunakan jasa produk digital yang mereka rasa penting mendukung dan memudahkan kegiatan harian.

Hasil crosstab Jenis Kelamin dan Pekerjaan 


\section{CAKrawWALA}

\section{Management Business Journal [[CM]-B]J] Volume 3 Nomor 1 Mei Tahun 2020}

Responden dalam penelitian ini dari kategori Jenis Kelamin dan Pekerjaan dijelaskan pada tabel .9. Untuk laki-laki (51 orang) pengguna produk digital pontianak sebagian besar adalah wirasawasta dan pegawai swasta. Untuk perempuan (49 orang) pengguna produk digital pontianak sebagian besar adalah pegawai swasta dan pelajar atau mahasiswa.

Tabel 10.

crosstab Jenis Kelamin dan Pekerjaan

\begin{tabular}{|c|c|c|c|c|c|c|c|c|}
\hline \multicolumn{9}{|c|}{ JK * pekj Crosstabulation } \\
\hline & & & \multicolumn{5}{|c|}{ Pekj } & \multirow[b]{2}{*}{ Total } \\
\hline & & & 1,00 & 2,00 & 3,00 & 4,00 & 5,00 & \\
\hline \multirow[t]{10}{*}{ JK } & \multirow[t]{5}{*}{1,00} & Count & 10 & 21 & 20 & 0 & 0 & 51 \\
\hline & & Expected Count & 5,1 & 10,7 & 19,9 & 9,2 & 6,1 & 51,0 \\
\hline & & \% within JK & $19,6 \%$ & $41,2 \%$ & $39,2 \%$ & $0,0 \%$ & $0,0 \%$ & $100,0 \%$ \\
\hline & & \% within pekj & $100,0 \%$ & $100,0 \%$ & $51,3 \%$ & $0,0 \%$ & $0,0 \%$ & $51,0 \%$ \\
\hline & & $\%$ of Total & $10,0 \%$ & $21,0 \%$ & $20,0 \%$ & $0,0 \%$ & $0,0 \%$ & $51,0 \%$ \\
\hline & \multirow[t]{5}{*}{2,00} & Count & 0 & 0 & 19 & 18 & 12 & 49 \\
\hline & & Expected Count & 4,9 & 10,3 & 19,1 & 8,8 & 5,9 & 49,0 \\
\hline & & $\%$ within JK & $0,0 \%$ & $0,0 \%$ & $38,8 \%$ & $36,7 \%$ & $24,5 \%$ & $100,0 \%$ \\
\hline & & \% within pekj & $0,0 \%$ & $0,0 \%$ & $48,7 \%$ & $100,0 \%$ & $100,0 \%$ & $49,0 \%$ \\
\hline & & $\%$ of Total & $0,0 \%$ & $0,0 \%$ & $19,0 \%$ & $18,0 \%$ & $12,0 \%$ & $49,0 \%$ \\
\hline \multirow[t]{5}{*}{ Total } & & Count & 10 & 21 & 39 & 18 & 12 & 100 \\
\hline & & Expected Count & 10,0 & 21,0 & 39,0 & 18,0 & 12,0 & 100,0 \\
\hline & & \% within JK & $10,0 \%$ & $21,0 \%$ & $39,0 \%$ & $18,0 \%$ & $12,0 \%$ & $100,0 \%$ \\
\hline & & $\%$ within pekj & $100,0 \%$ & $100,0 \%$ & $100,0 \%$ & $100,0 \%$ & $100,0 \%$ & $100,0 \%$ \\
\hline & & $\%$ of Total & $10,0 \%$ & $21,0 \%$ & $39,0 \%$ & $18,0 \%$ & $12,0 \%$ & $100,0 \%$ \\
\hline
\end{tabular}

\section{Hasil Chi Square Test}

Chi square test digunakan untuk menguji apakah ada asosiasi atau hubungan antara pekerjaan dan jenis kelamin. Hasil chi square menunjukkan nilai sebesar 61, 010 dengan probabilitas signifikan 0,000 . Oleh karena signifikansi $<0,05$ maka dapat disimpulkan terdapat hubungan antara pekerjaan dan jenis kelamin pengguna produk digital asli pontianak.

Tabel 11.

Chi -Square Tests

Chi-Square Tests

Asymptotic

Value

Df Significance (2-sided)

\begin{tabular}{l|r|r|r}
\hline Pearson Chi-Square & $61,010^{\mathrm{a}}$ & 4 &, 000 \\
\hline Likelihood Ratio & 84,550 & 4 &, 000 \\
\hline Linear-by-Linear Association & 53,753 & 1 &, 000 \\
\hline N of Valid Cases & 100 & & \\
\hline
\end{tabular}

a. 1 cells $(10,0 \%)$ have expected count less than 5 . The minimum expected count is 4,90 .

Hasil ini menunjukkan bahwa pengguna produk digital pontianak dari segi pekerjaan dan jenis kelamin adalah laki-laki yang bekerja sebagai wirasawasta dan pegawai swasta. Untuk 


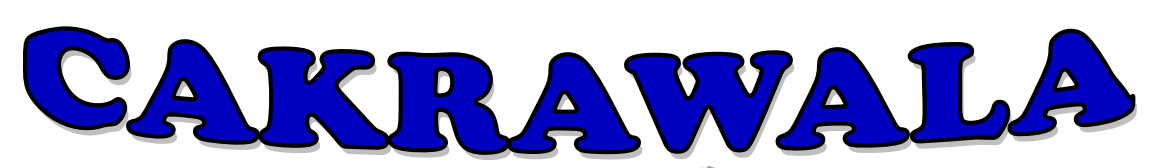

\section{Management Business Journal [C,M-B]] Volume 3 Nomor 1 Mei Tahun 2020}

perempuan bekerja sebagai pegawai swasta dan pelajar atau mahasiswa. Dominasi peran dari pegawai swasta baik laki-laki dan perempuan menjadi fokus utama bagi pemilik produk digital. Pegawai swasta adalah pasar potensial untuk digarap. Hal ini disebabkan oleh waktu kerja yang panjang dan kaku (sulit untuk meninggalkan pekerjaan) antara $8-10$ jam perhari menjadikan mereka sangat bergantung pada aplikasi-aplikasi berbasis teknologi seperti ini untuk memudahkan kegiatan rutin operasional mereka.

\section{PEMBAHASAN}

Keseluruhan hasil pengolahan data berkontribusi pada pemetaan karakteristik responden dan segmentasi pasar pada masing-masing produk digital Kota Pontianak. Hasil pengolahan data melalui metode crosstabulation diperoleh kesimpulan sebagai berikut : Chi square test untuk menguji asosiasi atau hubungan antara usia dan pendapatan menunjukkan nilai sebesar 246,576 dengan probabilitas signifikan 0,000. Oleh karena signifikansi $<0,05$ maka dapat disimpulkan terdapat hubungan antara usia dan pendapatan. Temuan ini memberikan peluang bagi start up digital asli Kota Pontianak untuk melakukan segmentasi pasar berdasarkan usia dan pendapatan pengguna jasanya. Bahwa pengguna jasa produk digital asli Kota Pontianak ini adalah responden usia $23-27$ orang sebanyak 26 orang dan mayoritas pada tingkat pendapatan $2-2,5$ juta. Mereka adalah generasi milenial yang peka terhadap teknologi pada tingkat pendapatan menengah kebawah.

Chi square test untuk menguji asosiasi atau hubungan antara usia dan frekuensi menggunakan menunjukkan nilai sebesar 179,630 dengan probabilitas signifikan 0,000. Oleh karena signifikansi < 0,05 maka dapat disimpulkan terdapat hubungan antara usia dan frekuensi menggunakan produk digital. Temuan ini memberikan petunjuk kepada para start up digital asli Kota Pontianak untuk menawarkan paket promo dan layanan spesial bagi pengguna dengan jumlah frekuensi tertentu, yang dari hasil olah data ternyata berkorelasi dengan usianya. Menyesuaikan promo dan layanan berdasarkan usia pengguna jasanya. Misalnya Usia 38-42 tahun sebanyak 21 orang didominasi oleh mereka dengan frekuensi menggunakan sebanyak 3 kali. Pada usia tersebut pengguna lebih menyukai promo dan layanan diskon harga atau voucher cash back setelah pembelian sejumlah tertentu.

Chi square test untuk menguji asosiasi atau hubungan antara pendidikan dan jenis kelamin menunjukkan nilai sebesar 83,994 dengan probabilitas signifikan 0,000. Oleh karena signifikansi < 0,05 maka dapat disimpulkan terdapat hubungan antara pendidikan dan jenis kelamin pengguna produk digital asli pontianak. Temuan ini juga menjadi referensi bagi para start up digital asli Kota Pontianak untuk mengembangkan fitur dan kecanggihan aplikasi karena pendidikan dan jenis kelamin menunjukkan korelasi yang signifikan. Pengguna usia muda dan dominasi wanita merupakan peluang pengembangan usaha.

Chi square test untuk menguji asosiasi atau hubungan antara pekerjaan dan jenis kelamin. menunjukkan nilai sebesar 61,010 dengan probabilitas signifikan 0,000. Oleh karena signifikansi < 0,05 maka dapat disimpulkan terdapat hubungan antara pekerjaan dan jenis kelamin pengguna produk digital asli pontianak. Temuan ini menunjukkan bahwa beberapa kategori pekerjaan tertentu dominan menggunakan jada para start up digital asli Kota Pontianak, serta ada korelasi signifikan 


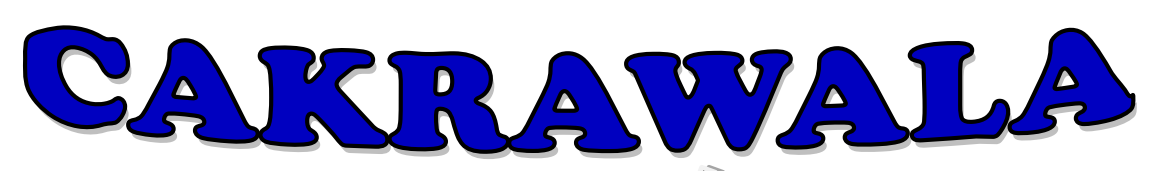

\section{Management Business Journal [CM:-B]] Volume 3 Nomor 1 Mei Tahun 2020}

dengan jenis kelamin mereka. Segementasi pasar menjadi semakin detail dan pasar spesifik dapat dilayani dengan lebih baik.

\section{KESIMPULAN}

Hasil pengolahan data melalui metode crosstabulation diperoleh kesimpulan sebagai berikut : (1) Chi square test untuk menguji asosiasi atau hubungan antara usia dan pendapatan ; (2) Chi square test untuk menguji asosiasi atau hubungan antara usia dan frekuensi menggunakan; (3) Chi square test untuk menguji asosiasi atau hubungan antara pendidikan dan jenis kelamin ; (4) Chi square test untuk menguji asosiasi atau hubungan antara pekerjaan dan jenis kelamin, menunjukkan hasil yang signifikan dengan nilai signifikansi $<0,05$. Maka, dapat disimpulkan bahwa usia dan pendapatan, usia dan frekuensi menggunakan, pendidikan dan jenis kelamin serta pekerjaan dan jenis kelamin pengguna produk digital asli Kota Pontianak memiliki korelasi hubungan yang saling mempengaruhi sehingga potensial untuk dilakukan pengelompokkan segmentasi pelanggan berdasarkan kategori tersebut.

\section{REKOMENDASI}

Sampel sebanyak 100 responden untuk mewakili tiga (3) aplikasi digital menjadi keterbatasan dalam generelasi peneltian secara luas. Hasil ini menjadi dasar yang penting bagi pemilik produk digital pontianak untuk mempertimbangan hasil penelitian ini dalam memperbaiki kebijakan bisnisnya. Bahwa usia, jenis kelamin, pendidikan, pekerjaan, pendapatan dan frekuensi menggunakan saling berhubungan dan dapat dipetakan secara spefisifik untuk mempertajam segmen pelanggan. Kajian mendalam dapat menentukan spesifikasi segmen pasar potensial perusahaan yang jika digarap dengan serius akan berdampak strategis bagi kemajuan usaha dalam jangka panjang.

\section{DAFTAR REFERRENSI}

A. Coe, G. Paquet, and J. Roy, "E-Governance and smart communities : A sosial learning challenge", Social Science Computer Review, vol. 19 no. 1, pp. 80-93, spring 2001.

A. Cocchia, "Smart and digital city: A systemic literature review", in Smart City, Progress in IS, R.P. Dameri and C. Rosenthal-Sabroux, Eds. Switzerland: Springer International Publishing, pp. 13-43, 2014.

A. Caragliu, C. Del Bo, and P. Nijkamp, "Smart cities in Europe", Journal of Urban Technology, vol. 18(2), pp. 65-82, 2011.

Dameri, R.P, "Searching for smart city definition: a comprehensive proposal", International Journal of Computers \& Technology, vol. 11(5), pp. 2544-2551, 2013.

Dawes, S. S., Cresswell, A. M., \& Pardo, T. A. From "need to know" to "need to share": Tangled problems, information boundaries, and the building of public sector knowledge networks. Public Administration Review, 2009; 69(3), 392-402. 


\section{Carcrawala}

Djaswadi,G.A, Wibawa,B.M dan Kunaifi.A, "Analisis Dekriptif dan Tabulasi Silang Konsumen Taxi Ride Sharing", Jurnal Sains dan Seni ITS. 2017. Vol 6 No.2

Ghozali, I. Analisis Multivanate dengan program SPSS. Edisi ke 2. Universitas Diponegoro. 2001.

Kotler, Philip dan Gary, Amstrong, Principles of Marketing, 2012, Pearson Education, New Jersey

Kuncoro, Mudrajad. Metode Riset untuk Bisnis dan Ekonomi. Jakarta: Erlangga. 2003.

Pradita.N.A, “Analisis Hubungan Antara Karakteristik Responden dengan Faktor yang Mempengaruhi Keputusan Konsumen menjadi Member Tupperware", Skripsi Universitas Sanata Dharma. 2015

Pike Research on Smart Cities [dedicates entire section to World sensing]. [Online]. 2011; Available: http://www.pikeresearch.com/research/smart-cities.

Sugiyono. Metode Penelitian Kuantitatif, kualitatif dan R \& D. Bandung: Alfabeta. 2011.

United Nations. World Urbanization Prospects. United Nations, Department of Economic and Social Affairs, Population Division: the 2011 Revision: Highlights. 2012. 